\title{
Management of public enterprises through public private partnership in Nigeria
}

\author{
Muhammad Abdullahi, Rilwan Nakazalle Usman \\ Department of Public AdministrationFederal Polytechnic, Kaura Namoda, \\ Zamfara State, Nigeria
}

\begin{abstract}
Collaboration with corporations, small businesses, non-governmental organizations and civil society organizations to provide socially beneficial goods and services. Public enterprises and the private sector cooperate in providing services and infrastructure through a variety of mechanisms. The level of performance and development of public enterprise in the country are very low due to corruption, management inefficiencies, overstaffing and inflation. This paper therefore in tend to highlight the different mechanisms of public private partnership (PPPs) in the management of public enterprise including concessions, build-operate- and- transfer (BOTs) arrangement, joint ventures and informal and voluntary cooperation as applied in some Latin American and Asian countries. The paper recommends that the government should clearly identify goals and objectives of public private partnerships and embody them in an official set of laws, develop strategy for management plan for public private partnerships and create employment protection measures for current government employees in organization that will go in to public private partnerships.
\end{abstract}

Keywords: Management; Public Enterprises (PEs); Public Private Partnership

\section{INTRODUCTION}

Since the 1930s and particularly after World War II, numerous state owned enterprises (SOEs) also called public enterprises (PEs). Were created in both developed and developing countries to address market deficits and capital short falls promote economic development, reduce mass unemployment and ensure national control over the overall direction of the economy, especially in developing countries.

By providing capital and technology to strategic areas where the private sector either shied away from or lacked the capacity to invest (such as heavy industries, infrastructure etc), most governments resorted to PEs to increase capital formation, produce essential goods at lower cost create employment and generally contribute to the economic development of the nation state.

However, rising corruption, management inefficiencies over staffing (without due regard to their economic viability many government treated PEs as easy conduits for job creation and convenient vehicle for patronage distribution). Inflation and rising current account deficits of the 1980s exposed serious government failures and limits of public enterprise as major players in economic development many public enterprises also suffered from technological short comings imported through foreign aid or soft loans from abroad. Many of the public enterprises 
where either equipped with low or second grade machineries contributing to low capital output Ratio, or were established without due regard to their economic and financial sustainability.

As a result of these failures, reforms of public enterprises were undertaken in the 80 s and 90s, with the vital support of multilateral financial institutions. The collapse of the Soviet Union also removed ideological and political barriers that hindered capitalist/market oriented reforms. Among the reforms alternatives available to government are:

1. Internal Management and Governance Reform

2. Commercialization or Marketilization

3. Outsourcing or Contracting Out

4. Public Private Partnership

5. Privatization or Liquidation

\section{MANAGEMENT OF PUBLIC ENTERPRISES}

Public enterprise can be considered as an organization established by the government under public private law as a legal personality which is autonomous or semi-autonomous produces/provides goods and services on a full or partial self - financing basis, and which the government or public body or agency participate by way of having shares or representation in its decision making structure the railways, post office are completely state owned, steel industry, electricity generations, fertilizer production etc. are owned by government also by joint stock companies.

According to Bureau of Public Enterprises (BPE) Nigeria (2000). The reasons for the establishment of PEs are as follows:

1. Shortage of local capital for expansion and technological improvements

2. Control of commanding height by government to prevent a few elite enriching themselves at the expense of majority of Nigerians.

3. Correction of market failure resulting from monopoly and misallocation of public resources

4. Facilitating regional development through location of PEs and their branches

5. Job creation and provision of social services.

\section{TYPES OF PUBLIC ENTERPRISE AND THEIR MANAGEMENT}

They are three types of public enterprise.

1. Government Departmental Organization

2. Public Corporations

3. Government Companies

1. Government Department Organization: The enterprises are organized like any other government departments. These are manage in two ways

i. Management through concerned ministry: It is managed by the officials of the government under the charge of the secretary of the ministry concerned. The examples are post office, railways, defense industries, broadcasting etc.

ii. Management by Inter-department committee or board in some organizations cooperation is required from several ministries. Therefore a board or committee of 
representative from concern ministry is formed so that cooperation, consultation and quick decisions may be taken.

2. Public Corporation: A public corporation is wholly owned by the government centre or state. It is established usually by a special act of the parliament with internal autonomy. Special statute also prescribes its management pattern, powers, duties and jurisdictions. Though the total capital is provided by the government, they have separate entity and enjoy independence in matters related to appointments, promotion etc. these corporations have no profit motive and work for maximization of social welfare.

3. Government Companies: A state enterprises can also be organized in the form of a joint stock company under companies Act. A government company in which not more than 51 $\%$ of the share capital is held by the central or any state government and partly by the central government and partly by one or more state governments. This form of enterprises is becoming very popular in recent times. It is created by an executive and not a legislative decision and is manage by elected board of directors which may include private individuals.

\section{MANAGEMENT OF PEs THROUGH PUBLIC - PRIVATE PARTNERSHIPS}

Public Private Partnerships: Is the improvement of the management of PEs through collaborations with corporations, small business, nongovernmental organizations (NGOs) and civil society organizations to provide socially beneficial goods and services. Public enterprises and the private sector cooperate in providing services and infrastructure through a variety of mechanisms including concessions, build - operate and transfer (BOTs) arrangements, joint ventures and informal and voluntary cooperation. Public private partnerships allow or encourage domestic and foreign owned business, community groups cooperatives, private voluntary associations, small enterprises and other non - governmental organizations (NGOs) to offer social services.

In some countries PPPs are an intermediate in privatizing SOEs or an alternative to privatization. Joint ventures are one means by which public enterprises work with the private sector through mergers, partial acquisitions of state won enterprises (retaining some share of the stock in profitable or politically strategic enterprises) or joint ownership by government and private investors.

In Oman, for example, the government developed a joint venture between Omani public and private enterprises and sea land to expand and maintain its salalah container shipping port. In 2002, the municipality of Ajman in the United Arab Emirates formed a equal ownership joint venture the Ajman sewerage company with other companies, to invest and $\$ 100$ million in a waste water network that will deliver service to 300,000 people in the emirate. The government granted the joint venture 27 - year's concession in which the company will recover its costs by levying tariffs for service to be paid by customers. China has used joint ventures between foreign investors and state enterprises to obtain foreign technology investors and state enterprises to obtain foreign technology and capital, learn foreign management and marketing techniques, increase foreign exchange generating capacity, and promote joint research and development project.

Government around the world use turnkey projects with consortia of private companies to build telecommunications, transport, shipping, airport, utility and water and sewerage infrastructure. Governments in countries with both advanced and developing economies use build operate transfer (BOT) agreements in which they buy or lease completed facilities 
constructed by private investors after the companies have recouped their investment and a reasonable return by operating the facilities for an agreed - upon period of time.

The government of South Korea, for example used a BOT arrangement to develop and operate the Seu/Beltway and daegu Pusan highway as toll roads. It gave the Pusan Newport company sponsored by Samsung Corporation, CSX world terminals, and local Korean contracting companies a 50 - year secured concessions to develop a $\$ 900$ million Pusan port expansion project using the PPP approach.

The private infrastructure investment of Korea (PICKO) organization sought financing and participation from private firm around the world in constructing, financing and operating infrastructure in Korea BOT or build operate - own (BOO) arrangements have also been used extensively in Malaysia and Turkey to build telecommunication systems, highways, utilities and water supply systems, and operate them under a concession from the government. Debt financing is usually highly leveraged and the private consortium takes a small equities position.

The consortium usually seeks loans from international financing agencies and commercial banks using future revenues from the projects to repay them.

Another approach, a build operate - own transfer (BOOT) arrangement, has been used to construct and operate independent power plants in china (Shajiao project) and Pakistan (Hab River project) as well as in Dominican Republic and Costa Rica. These projects usually involve limited resources financing in which capital is raised on the basis of cash flows and not on the collateral of project owners.

Although they offer government in developing countries important means of expanding services and infrastructure and the private sector commercial opportunities to expand their businesses, public - private partnerships are complex arrangements and can create potential problems for both the public and the private sectors if they are not properly designed and administered.

They often displace public workers, thereby generating political opposition among public officials, labor unions and public employee associations. If PPPs are not well designed and supervised their services can become more expensive than those provided by government. Poorly designed and inadequate analyzed projects have failed in both rich and poor countries. Corruptions undermine public trust in PPPs if the contracting process is not transparent and carefully supervised. Lack of sufficient competition can turn PPPs into private state own enterprises. Overly restricting concessions or creating too many can deprive PPPs of economics of scale.

If government regulation is too stringent it can lead to deficiencies of service provision and if it is too lax it may not hold private service providers sufficiently accountable. The cost of contract management can be substantial. In all cases, governments' must compare carefully the cost of contracting out with the costs of providing services directly. The involvement of the private sector or providing service that ware formally free or that were subsidized by the government can increase their price and place poor segments of the population at a significant disadvantage.

\section{ROLES OF GOVERNMENT}

Experience suggests that in order to be effective governments must take the following actions to manage public - private partnerships.

1. Clearly identify goals and objective of public private partnerships and embody them in an official set of laws

2. Develops strategic management plan for PPPs 
3. Create an effective PPPs agency

4. Select appropriate methods of PPPs

5. Develop clear and transparent PPPs procedure

6. Apply appropriate assessment and valuation methods

7. Create effective financial structures for private sector participation

8. Establish an effective system of government supervision and regulation especially for natural monopolies

9. Help strengthen private sector management capacity

10. Create employment protection measures for current government employees in organization that will go to PPPs

\section{CONCLUSIONS}

In order to achieve an efficient management of public enterprises through public private partnership in Nigeria, the following recommendation should be considered:-

(i) There is the need to implement with seriousness, the reforms of public enterprises through Public Private Partnership.

(ii) There is a need to formulate a comprehensive National implementation framework for Public Private Partnership in a timely, transparent and proactive manner.

\section{References}

[1] Bala, K. and Yakubu, N. (2000). "Partnership In The Provision Of Water Supply" Paper

[2] Presented At A National Seminar On Environment: Imperatives For Research, Development And Management College Of Environment Studies Kaduna Polytechnic, pp. 7.

[3] Ezeh, E.M. (2003). "Privatization Of Engineering Infrastructure In Nigeria The Role of The Engineering Family". Proceedings Of Council For The Regulation Of Engineering In Nigeria (COREN) 12 $2^{\text {th }}$ Engineering Assembly, Abuja, pp. 22.

[4] Gana, J.S.S. (2001). "Entrepreneurship" Jofegan Associates, Kaduna, pp. 59.

[5] Lugard A.A (2005)" Options Available For Private Sector Participation In The Provision of Potable Water In Nigeria" Being A Paper Presented At The $3{ }^{\text {rd }}$ Seminar Organized By The School Of Engineering Technology, Federal Polytechnic Kaura Namoda

[6] Tomáš Hes, Anna Poledňáková, International Letters of Social and Humanistic Sciences 2 (2013) 18-31.

[7] Mohsen Mehrara, Masoumeh zirak, International Letters of Social and Humanistic Sciences 2 (2013) 32-38.

[8] Taiwo Adewale Muritala, Ismail O. Fasanya, International Letters of Social and Humanistic Sciences 2 (2013) 39-50.

[9] Borowski A., International Letters of Social and Humanistic Sciences 3 (2013) 46-53.

[10] Borowski A., International Letters of Social and Humanistic Sciences 3 (2013) 69-74.

[12] Donovan A. McFarlane, International Letters of Social and Humanistic Sciences 4 (2013) 35-44.

[13] Rajesh K. Yadav, Nishant Dabhade, International Letters of Social and Humanistic Sciences 4 (2013) 49-69.

[14] Borowski A., International Letters of Social and Humanistic Sciences 4 (2013) 70-74. 
[15] Paul Bukuluki, International Letters of Social and Humanistic Sciences 5 (2013) 27-44.

[16] Mohsen Mehrara, Maysam Musai, International Letters of Social and Humanistic Sciences 5 (2013) 55-62.

[17] Debiprasad Mukherjee, International Letters of Social and Humanistic Sciences 6 (2013) 41-48.

[18] Tomáš Hes, Alena Neradová, Karel Srnec, International Letters of Social and Humanistic Sciences 7 (2013) 55-75.

[19] Kinga Dziwańska, International Letters of Social and Humanistic Sciences 7 (2013) 96-112.

[20] Borowski A., International Letters of Social and Humanistic Sciences 7 (2013) 113-118.

[21] Mohsen Mehrara, Maysam Musai, International Letters of Social and Humanistic Sciences 8 (2013) 1-7.

[22] Jacek Tittenbrun, International Letters of Social and Humanistic Sciences 11 (2013) 10-34.

[23] Mohsen Mehrara, Hamid Abrishami, Mostafa Boroujli, Mahan Amin, International Letters of Social and Humanistic Sciences 11 (2013) 76-83.

[24] Borowski A., International Letters of Social and Humanistic Sciences 11 (2013) 100-105.

[25] Sele Sylvester Ebisin, International Letters of Social and Humanistic Sciences 2 (2014) $1-9$.

[26] Tittenbrun J., International Letters of Social and Humanistic Sciences 2 (2014) 20-40.

[27] Borowski A., International Letters of Social and Humanistic Sciences 2 (2014) 110-121.

[28] Pawa Tersoo, International Letters of Social and Humanistic Sciences 3 (2014) 26-36.

[29] Rabi'u Muhammad Ishaq, International Letters of Social and Humanistic Sciences 3 (2014) 37-44.

[30] Adoga James Ada, International Letters of Social and Humanistic Sciences 3 (2014) 45-52.

[31] Bahram Meihami, Hussein Meihami, International Letters of Social and Humanistic Sciences 3 (2014) 80-91.

[32] Onyike Maggaret Odu, International Letters of Social and Humanistic Sciences 4 (2014) 31-39.

[33] Uloma Charity Oguzor, International Letters of Social and Humanistic Sciences 4 (2014) 97-104.

[34] Okezie A. Ihugba, Alex Odii, A. C. Njoku, International Letters of Social and Humanistic Sciences 5 (2014) 21-34.

[35] Okezie A. Ihugba, Bankoli Bankong, N. C. Ebomuche, International Letters of Social and Humanistic Sciences 5 (2014) 92-113. 